\title{
In vitro spore germination and early gametophyte development of Cibotium barometz (L.) J. Sm. in different media
}

\author{
YUPI ISNAINI, TITIEN NGATINEM PRAPTOSUWIRYO \\ Research Center for Plant Conservation and Botanic Gardens (Bogor Botanic Gardens), Indonesian Institute of Sciences. Jl. Ir. H. Juanda No. 13, Bogor \\ 16122, West Java, Indonesia. Tel.+62-251-8322187. Fax. +62-251-8322187, ^email: tienpferns@ gmail.com
}

Manuscript received: 2 October 2020. Revision accepted: 24 October 2020.

\begin{abstract}
Isnaini Y, Praptosuwiryo TNg. 2020. In vitro spore germination and early gametophyte development of Cibotium barometz (L.) J. Sm. in different media. Biodiversitas 21: 5373-5381. Cibotium barometz (L.) J. Sm. is known as the golden chicken fern and included in Appendix II of CITES. It is an important export commodity for traditional and modern medicine. Globally, populations of this species are under significant pressure due to overexploitation in the wild. In vitro culture is one of the technologies used for $e x$-situ propagation and conservation of rare and endangered ferns and lycophytes. This study's objectives were: (i) to observe in vitro spore germination and early gametophyte development of $C$. barometz, and (ii) to determine the best culture medium for rapid spore germination and early development of the gametophytes. The sterilized spores were sown in half-strength Murashige \& Skoog ( $1 / 2 \mathrm{MS})$ basal medium supplemented with combinations of 6-Benzylaminopurine (BAP) and $\alpha$-Naphthalene acetic acid (NAA). A factorial combination of four BAP concentrations $\left(0,2,4\right.$, and $\left.6 \mathrm{mg} \mathrm{L}^{-1}\right)$ with four concentrations of NAA $\left(0 ; 0.01 ; 0.03\right.$ and $\left.0.05 \mathrm{mg} \mathrm{L}^{-1}\right) \mathrm{created}$ 16 treatments replicated in a Completely Randomized Design. Spore germination of $C$. barometz was observed to be Vittaria-type, and its prothallial development was Drynaria-type. Spore germination started 7-14 days after sowing. Young heart-shape gametophytes consisting of 110-240 cells were formed in 45-61 days after sowing. The two best spore culture media for rapid spore germination and development of $C$. barometz gametophytes were $1 / 2 \mathrm{MS}$ with or without $2 \mathrm{mg} \mathrm{L}^{-1} \mathrm{BAP}$.
\end{abstract}

Keywords: Ex-situ conservation, medicinal fern, propagation, spore culture

\section{INTRODUCTION}

Ferns and lycophytes are essential components of an ecosystem. They contribute $4 \%$ of the vascular plant diversity in the world (Mehltreter 2020). They are also vital components of the ecosystems of biological hot spots, exceptionally moist tropical forest and oceanic islands (Given 2002). These plant groups have received much attention as natural research material, as model organisms for studying plant evolution. The number of literature studies on ferns and lycophytes, especially in systematics and evolution, is relatively large (Ebihara and Nitta 2019), but ferns and lycophytes face an unprecedented threat due to human activities, such as fire and land-use change. By the year 2008, a global risk assessment using IUCN Red List had been completed for only $2 \%$ of the 11,000 species of ferns and lycophytes; $89 \%$ of these ferns were considered to be at risk (Mehltreter 2010). Rare and threatened ferns and lycophytes of Asia towards assessing globally threatened species have been published yet. Of the 886 taxa (835 species and 51 infraspecific taxa) enumerated, 577 occur in Southeast Asia, 215 in East Asia, and 101 in South Asia (Ebihara et al. 2012). We should well implement management strategies for ferns and lycophytes conservation in South Asia countries. In-situ protection of endangered fern species is recommended as a management strategy for fern conservation. However, exsitu cultivation of endangered fern species may supplement in-situ protection efforts but should not replace them (Meheltreter 2020).
Cibotium barometz is a tree fern having economic value as an export commodity for both traditional and modern medicine (Praptosuwiryo 2003; Zhang et al. 2008; Praptosuwiryo et al. 2011a; Lim and Lim 2016). Before 1997, China was the first exporter and also the top user country of C. barometz. China exported C. barometz's rhizomes to South Korea, the USA, and Canada with more than 500 tons in five years, over 1993-1997 (Zhang et al. 2008). The second exporter country of $C$. barometz was Vietnam, with its quota of 250,000 kg dry weight of sliced rhizome in 2009 and 2010 (UNEP-WCMC, 2010). Since 2006, under the regulation of CITES, Indonesia has been exported the dried hairs of $C$. barometz to French. The export quotas of $C$. barometz for Indonesia from the year 2006 to 2015 were $2500 \mathrm{~kg}$ (2006), $500 \mathrm{~kg}$ 2007), 450 (2008), $900 \mathrm{~kg}$ (2009 to 2016) (CITES Secretary 2006 2015).

The dry sliced rhizomes of Cibotium called "Gouji" are used for producing pills of "Zhuangyao Bushen Wan", a medicine which useful in maintaining the function of the kidneys (Zhang et al. 2008). Besides maintaining the function of the kidneys, C. barometz has been used to treat various illnesses. Polysaccharides of $C$. barometz is used for the treatment of osteoarthritis ( $\mathrm{Fu}$ et al. 2017). An extract from the rhizome is also used as an anti-rheumatic, antioxidant, antimicrobial activities, antidermatophytic activity, and as a gastric ulcer (Praptosuwiryo 2003; AlWajeeh et al. 2017a,b; Wang et al. 2017a,b; Xie et al. 2017; Huang et al. 2018a,b; Sit et al. 2018; He et al. 2019; Heng et al. 2020; Musman et al. 2020). 
In several countries, the $C$. barometz populations have decreased rapidly due to the overexploitation for trade for medicinal purposes (Zhang et al. 2008; Nguyen et al. 2009). Since 1976, this species was included in Appendix II of the Convention on International Trade in Endangered Species (CITES) for trade monitoring (Praptosuwiryo 2003; Zang et al. 2002; Praptosuwiryo et al. 2017; Liu et al. 2018; Schippmann 2018). It means that no export is allowed without a prior permit issued by the CITES committee under the regulation of each country's management authority. Therefore, various conservation efforts and strategies should be implemented to ensure that this species will sustain in nature.

Ex-situ conservation for rare and or exploited pteridophyte species can be supported by collecting live specimens from the wild, growing them in pots from spores, and propagating them from rhizomes (Mehltreter 2010). However, conventional cultivation of ferns from spores is generally more time-consuming. In vitro culture technology can be used as an alternative method for propagation and conservation of ferns and lycophytes (Makowski et al. 2016; Jang et al. 2019a). Many ferns and a few lycophytes have been grown in vitro (Moura et al. 2015; Luna et al. 2016, Jang et al. 2017; Kwon et al. 2017; Ballesteros and Pence 2018; Castilho et al. 2018; Johnson and Shibila 2018; Jang et al. 2019a,b; Romanenko et al. 2019; Jang et al. 2020; Park et al. 2020; Shelikhan 2020; Van Nguyen et al. 2020; Zhang et al. 2020). In vitro culture requires less space than whole plants' culture and can be kept free from disease. In vitro culture methods offer the chance to study the development stages of fern species from gametophyte to sporophyte (Simões-Costa et al. 2015; Ravi 2016; Cho et al. 2017; Park et al. 2019), and the opportunity to understand better their abiotic demands (Manonmani and Sara 2014). Therefore, in vitro culture can provide data to develop efficient propagation strategies for conserving ferns (Shelikhan 2020).

Studies dealing with the Cibotium propagation are only a few. Goller and Rybczyński (2007) studied in vitro culture of $C$. glaucum (Sm.) Hook. \& Arn. and C. schiedei Schltdl. \& Cham. using spores as explants. Chen et al. (2007) studied the gametophyte development and its diversity in $C$. barometz from China by culturing spores in Knop's solution and solid medium. Li et al. (2010) and Xu et al. (2010) reported their work on the in vitro culture and plant regeneration of $C$. barometz using Murashige \& Skoog (MS) media. Yu et al. (2016a) investigated gametophyte development and apogamy of $C$. barometz by culturing sterile spores. Yu et al. (2016b) reported green globular bodies induction on half-strength MS media supplemented with Thidiazuron and $\alpha$-Naphthaleneacetic acid (NAA). This paper reports our study on the in vitro propagation of $C$. barometz from Sumatra. The study aims were: (1) to observe spore germination and early gametophyte development of $C$. barometz grown in vitro, and (2) to determine the best spore culture media for rapid spore germination and early development of the gametophytes.

\section{MATERIALS AND METHODS}

\section{Study taxon}

Cibotium barometz (L.) J. Sm. is a tree fern belonging to the family Cibotiaceae (Smith et al. 2006). This species can be easily recognized by the existence of smooth, shiny, golden hairs covering its rhizome and basal stipes, with 210 or more pairs of cup-shaped sori on each pinnule-lobe (Holttum 1963; Rugayah et al. 2009; Praptosuwiryo et al. 2011; Praptosuwiryo et al. 2017). This species is distributed in the tropical and subtropical regions of Asia. It grows in warm and humid environments, in hilly or mountain forests, often in valleys, forest edges, and open places in forests at elevations ranging from 50 to $1600 \mathrm{~m}$ a.s.l. (Holttum 1963; Zhang et al. 2008; Rugayah et al. 2009; Praptosuwiryo et al. 2011; Praptosuwiryo et al. 2017). The national conservation status of $C$. barometz in Indonesia has been assessed using the 2012 IUCN Red List Categories and Criteria (version 3.1). This species is included in the vulnerable category (VU A4cd) (Praptosuwiryo and Rugayah 2017).

\section{Spore collection and sterilization}

Spores used as explants in this study were freshly collected from the plant growing in The Ecopark of Cibinong Sciences Center-LIPI (West Java). These plants were initially collected from the secondary forest at Soriak Hill, Lima Puluh Kota District, West Sumatra Province (Titien Ng Praptosuwiryo 3353). The spore collection procedure followed Praptosuwiryo et al. (2015): sporebearing pinnae of mature sporophylls were cleaned in running water to avoid spore contamination from other species and airy drained in a clean newspaper envelope. The dried spore-bearing pinnulae were then placed in an envelope $\left(22 \times 11 \mathrm{~cm}^{2}\right)$ and kept at room temperature in a dry place. A few days later (7-10 days), most of the spores had released from sporangia and lying on the envelope. The spores were separated from the sporangia by tilting the envelope paper and removing them from the envelope to a piece of glassine weighing paper folded into a pocket. The spore collections were kept at room temperature until the sowing day (not more than two weeks).

In fern propagation by in vitro culture method, spore sterilization is required before the germination procedure. Spores sterilization procedures followed those described by Isnaini (2013). Spores were sterilized with a commercial Clorox at a concentration of $20 \%, 10 \%$, and $5 \%$, respectively, with 1-2 drops of tween-80 as a wetting agent in $20 \mathrm{ml}$ of distilled water. The sterilized spores were rinsed three times in sterile distilled water for one minute each time to remove all traces of sterilant. All the sterilization works were carried out in sanitary conditions in a laminar flow cabinet.

\section{Spore culture in vitro on a half-strength MS medium supplemented with BAP and NAA.}

A completely randomized design with at least ten replications of a $4 \times 4$ factorial treatment arrangement was used in this experiment, which aimed to test the effectiveness of different media for spore germination and 
early gametophyte development of $C$. barometz. The basal medium was a half-strength Murashige and Skoog (1/2MS) medium. This basal medium was supplemented with various combinations of 6-Benzylaminopurine (BAP) and (NAA). There were four levels of concentration of BAP $(0$, 2,4 , and $\left.6 \mathrm{mg} \mathrm{L}^{-1}\right)$ and four levels of concentration of NAA $\left(0 ; 0.01 ; 0.03\right.$ and $\left.0.05 \mathrm{mg} \mathrm{L}^{-1}\right)$, combined in a factorial arrangement resulting in sixteen different spore culture media. Three percent of sugar was added to each medium as a carbon source. The $\mathrm{pH}$ of each medium was adjusted to $5.7 \pm 0.01$, then gel rite was used as a solidifying agent at a concentration of $0.2 \%$ weight/volume (w/v) before boiling them. The medium placed into the Erlenmeyer flask and sterilizing in an autoclave. The sterilized medium was poured into a Petri dish aseptically in a laminar airflow cabinet. The spores in sterile water were sown onto the media contained in $5 \mathrm{~cm}$ Petri dishes. Approximately 100200 spores were sown for each replicate. The Petri dishes were sealed with strips of plastic wrap film to inhibit drying and contamination. For germination, spores were incubated in Petri dishes at $20-25^{\circ} \mathrm{C}$ at 2000 lux with a 16 $\mathrm{h}$ photoperiod.

\section{Observation of spore germination and gametophyte development on $1 / 2$ MS media without BAP and NAA}

Spore germination was defined as the emergence of a rhizoid through the spore coat (Camloh 1993). Gametophytes were classified according to the development stages of fern gametophytes described by Rechenmacher et al. (2010), viz.: gametophyte with chlorocyte and rhizoid (chlorocyte and rhizoid stage), filamentous gametophyte (filamentous stage), and laminar gametophyte (laminar stage). In this study, the laminar stage was divided into two phases, the spatulate stage, and the early heart shape stage. Spore germination and prothallium development were observed from 10-13 to 5561 days after spore sowing (das). The percentage of rhizoid, filamentous, spatulate, and young heart shape stages were determined on $13,21,37$, and 61 das respectively.

\section{Effect of BAP in combination with NAA on in-vitro germination and early gametophyte development of Cibotium barometz.}

Five replicate Petri dishes were observed for each of the sixteen media. A spore was considered germinated when the first emergent cell became visible (Chuter et al. 2008). The number of gametophytes with chlorocyte and rhizoid, filamentous gametophyte, spatulate gametophyte, and early heart gametophyte were counted under a binocular Nikon SM2-10A microscope (objective lens 4.9x). Five field-ofview for each Petri dish were observed under the microscope. An Olympus microscope U-TV0, 5XC-3 $5 \mathrm{H} 12344$ ( $4 \times$ and $10 \times$ ) connected to a computer was used to document spore germination and gametophyte development at every week of observation.

\section{Statistical analysis}

Quantitative data of spore germination and gametophyte development were expressed as percentages and analyzed with SPSS 13.0. The data for spores germination and gametophyte development were tested by using the analysis of variance (ANOVA), and differences between means were tested by Duncan's test at $5 \%$ probability.

\section{RESULTS AND DISCUSSION}

\section{Spore germination and early gametophyte development stages of Cibotium barometz on $1 / 2$ MS media without BAP and NAA}

Spore germination of Cibotium barometz

Germination of spore is defined as the set of mechanisms occurring in the dormant spore that culminates with the growth of cells to form a sporeling able to be established in the substrate (Gabriel y Galán et al. 2015; Steinbrecher and Leubner-Metzger 2017; Yan and Chen 2020). Spore germination can be easily detected by observing signs of the emergence of particular organs such as radicle, protonema, filament or rhizoid (Suo et al. 2015; Penfield 2017; Elgabra et al. 2019). Spores of C. barometz are trilete, tri-radially symmetrical, non-chlorophyllous, and golden-yellow with a perine. In our experiment, at 3-6 days after sowing, $C$. barometz's spore became green in color (Figure 1.A.). The golden-yellow coloration of the spores changed to green, indicating that germination had started. It was followed by the breakage of spore walls to produce a prothallial filament, indicating the spores's successful germination. It is generally recognized that the criterion for spore germination is the emergence of the chlorocyte, or the rhizoid (Chuter et al. 2008; Marcon et al. 2015). Similar to Praptosuwiryo (2015) observations, the first cell produced from in vitro spore germination of $C$. barometz in this experiment was rhizoid. Therefore, it is called the rhizoid stage.

The second stage of gametophyte development was the chlorocyte-rhizoid or rhizoid-protocorm stage in which the spore bore both rhizoid and the first cell of a filament. The chlorocyte-rhizoid stage for $C$. barometz is illustrated in Figure 1.A. Spore germination started 7-14 days after sowing. It demonstrated that the period time for germination in vitro is not different from $C$. barometz spores grown conventionally in natural media. Praptosuwiryo et al. (2015) reported that C. barometz's spores sown conventionally in natural media germinated 7 15 days after sowing; bearing gametophytes with chlorocyte and rhizoid and the early stage of filamentous gametophytes, the filament consists of $1-4$ cells.

Referring to patterns of gametophyte development, Nayar and Kaur (1969) described seven different types of prothallial development in the homosporous ferns. In previous works of spore germination, Chen et al. (2017) reported that the germination of $C$. barometz from China belonged to the Vittaria-type and Cyathea-type. In our study, the spore germination of $C$. barometz from Sumatra also belonged to Vittaria-type. The first division giving rise to the rhizoid initial was perpendicular to the spore's polar axis, and the second division yielding the protonema initial was perpendicular to the first (Figure 1.B.). Deng et al. (2007) and Praptosuwiryo et al. (2015) also reported only 
one type of spore germination of $C$. barometz, the Vittariatype. A similar types of spore germination also reported in Aglaomorpha cornucopia (Huang et al. 2015), Lepisorus nudus (Singh et al. 2017), Microgramma mortoniana and
Pleopeltis macrocarpa (Gorrer et al. 2018). FarfánSantillán (2017) reported two types of germination of Gleichenia and Cyathea; and three types of prothallial development Marattia, Osmunda and Drynaria.

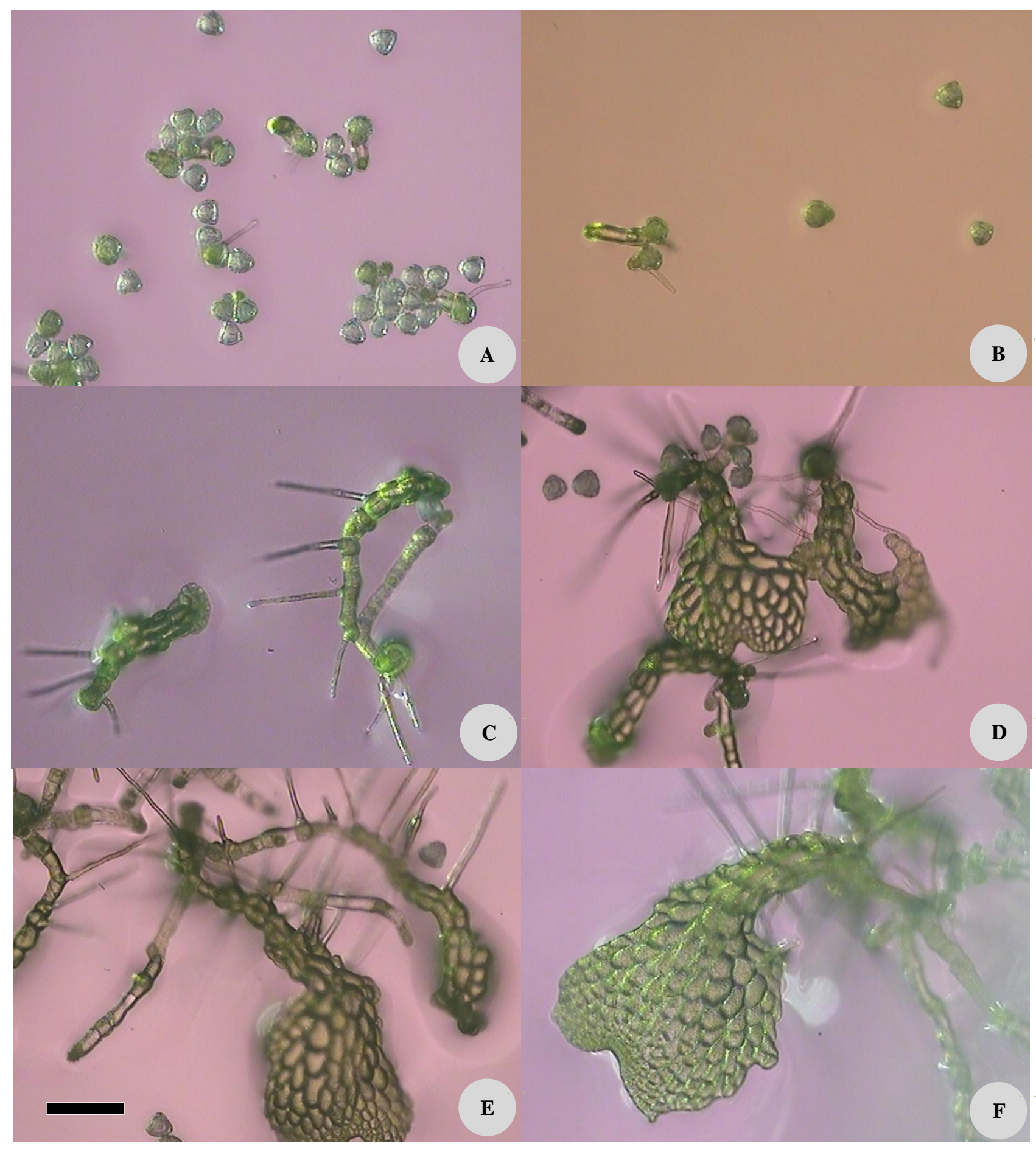

Figure 1. Spore germination and early development of Cibotium barometz on $1 / 2 \mathrm{MS}$ media (NAA $0 \mathrm{mgL}^{-1}$ and BAB $0 \mathrm{mg} \mathrm{L}^{-1}$ ). A. Spore becoming green in color in the process of germination; rhizoid and chlorocyte ( 15 days after sowing). B. Early stage of filamentous prothallus composed of three cells, showing Vittaria-type of spore germination (16 days after sowing); C. Filamentous stage of prothallus composed of 11 cells and spatulate stage of prothallus composed of 29 cells ( 23 days after sowing); D. Early stage of young heart-shape gametophyte composed of 69 cells (43 days after sowing); E. Young heart-shape gametophyte composed of 115 cells (46 days after sowing); F. Young heart-shape gametophyte composed of 233 cells (56 days after sowing). Bar $=200 \mu \mathrm{m}$ for all. 
Early gametophyte development stages of Cibotium barometz

Gametophyte development of $C$. barometz in vitro culture is of the Drynaria-type (Nayar and Khaur 1969). The same type of gametophyte development is reported in Adiantum capillus-veneris L. (Oloyede et al 2017), Lepisorus nudus (Singh et al. 2017), Microgramma mortoniana, and Pleopeltis macrocarpa (Gorrer et al. 2018). As also described by Praptosuwiryo et al. (2015), when at the fimentous stage (prothallus has 5-10 or more cells) one of the cells at the top margin of the prothallus (the anterior marginal cells) then divides obliquely across its width (Figure 1.C.). This results in obconical meristematic cells. Division by this type of cell is parallel to each other and perpendicular to the rest of the cells, forming rows. This results in the formation of a notch at the prothallus's anterior edge, giving it a roughly heart-shaped appearance. Young heart-shape gametophytes consisting of 110-240 cells were formed in 45-61 days after sowing (Figure 1.E-F).

\section{Effect of BAP in combination with NAA on in-vitro germination and early gametophyte development of Cibotium barometz.}

A basal medium of $1 / 2 \mathrm{MS}$ has often is used as a medium for in vitro spore culture in ferns such as Polystichum craspedosorum (Shelikhan 2020) and C. barometz (Li et al. 2010). The effect of BAP in combination with NAA on in vitro germination and early gametophyte development of C. barometz is shown in Table 1 and Figure 2. The highest spore germination, indicated by the percentage of the rhizoid stage (spores give rise rhizoids) and filamentous stage, was on $1 / 2 \mathrm{MS}$ media with $2 \mathrm{mg} \mathrm{L}^{-1} \mathrm{BAP}$ and 0 or $0.01 \mathrm{mg} \mathrm{L}^{-1}$ NAA. Visual observation at 13 days after sowing showed that most of the cultured spores grew well and looked green in color on $1 / 2 \mathrm{MS}$ basal medium supplemented with $2 \mathrm{mg} \mathrm{\textrm {L } ^ { - 1 }} \mathrm{BAP}$ or without BAP supplementation. Increasing with BAP to 4 and $6 \mathrm{mg} \mathrm{L}^{-1}$ did not result in better spore germination and early gametophyte development of $C$. barometz.

In a study of the fern Asplenium nidus, a basal medium of $1 / 2$ MS supplemented with BAP and NAA growth regulators at concentrations of $2 \mathrm{mg} \mathrm{L}^{-1}$ and $0.5 \mathrm{mg} \mathrm{L}^{-1}$ respectively produced a significant increase in multiplication (Khan et al. 2008). Higuchi and Amaki (1989) also studied the effects of BAP and NAA concentration on the growth of in vitro plantlets of Asplenium nidus. The number of $A$. nidus plantlets were less at low concentrations of BAP and NAA. At higher concentrations, the explants started to show browning, which suggested the detrimental effect of higher doses. This reflects that plants need both auxins and cytokinins which should be supplied in the medium and the ratio between them seems to be very important for multiplication (Bertrand et al. 1999; Fernandez et al. 1999; Rocha et al 2015). Many reports in which the application of growth regulators either enhances or suppresses plant growth depending on the concentrations used and their relative proportions (Fernandez and Revilla 2003; Abbasi 2017; Smýkalová et al. 2019).

Table 1. The percentage (mean \pm standard deviation) of the prothallus stage of Cibotium barometz observed along with the spore germination and developmental stages of gametophyte, between 10-61 days after sowing on media comprising half-strength Murashige \& Skoog medium (1/2 MS) with 6-Benzylaminopurine (BAP 0, 2,4, and $6 \mathrm{mg} \mathrm{L}^{-1}$ ) and 1-Naphthaleneacetic acid (NAA 0;0.01; 0.03 and $\left.0.05 \mathrm{mg} \mathrm{L}^{-1}\right)$.

\begin{tabular}{|c|c|c|c|c|c|}
\hline \multirow{2}{*}{$\begin{array}{l}\text { BAP } \quad(\mathbf{m g} \\
\left.\mathbf{L}^{-1}\right)\end{array}$} & \multirow{2}{*}{$\begin{array}{l}\text { NAA } \quad(m g \\
\left.\mathbf{L}^{-1}\right)\end{array}$} & \multicolumn{4}{|c|}{$\begin{array}{l}\text { Percentage of prothallus stage along with the spore germination and developmental stages of } \\
\text { gametophyte. 10-61 days after sowing (das)* }\end{array}$} \\
\hline & & $\begin{array}{l}\text { Rhizoid stage } \\
\text { (10-13 das) }\end{array}$ & $\begin{array}{l}\text { Filamentous Stage } \\
\text { (16-21 das) }\end{array}$ & $\begin{array}{l}\text { Spatulate Stage } \\
(23-37 \text { das })\end{array}$ & $\begin{array}{l}\text { Heart Shape Stage } \\
(55-61 \text { das })\end{array}$ \\
\hline 0 & 0 & $71.66 \pm 7.84^{\mathrm{a}}$ & $16.44 \pm 6.41^{\mathrm{b}}$ & $26.15 \pm 8.85^{\mathrm{abc}}$ & $1.60 \pm 0.07^{\mathrm{ab}}$ \\
\hline 0 & 0.01 & $52.99 \pm 8.37^{\mathrm{abc}}$ & $16.92 \pm 9.41^{b}$ & $27.07 \pm 5.93^{\mathrm{ab}}$ & $1.72 \pm 0.87^{\mathrm{ab}}$ \\
\hline 0 & 0.03 & $32.99 \pm 7.04^{\text {cdefg }}$ & $21.88 \pm 2.95^{\mathrm{b}}$ & $8.70 \pm 5.79^{\mathrm{cd}}$ & $0.71 \pm 0.51^{\mathrm{ab}}$ \\
\hline 0 & 0.05 & $24.74 \pm 5.65^{\mathrm{fg}}$ & $22.02 \pm 6.99^{b}$ & $2.73 \pm 3.02^{\mathrm{d}}$ & $0.00 \pm 0.00^{\mathrm{b}}$ \\
\hline 2 & 0 & $71.63 \pm 6.34^{\mathrm{a}}$ & $28.65 \pm 2.86^{\mathrm{b}}$ & $35.37 \pm 6.32^{\mathrm{a}}$ & $4.06 \pm 0.11^{\mathrm{a}}$ \\
\hline 2 & 0.01 & $58.20 \pm 8.98^{\mathrm{ab}}$ & $55.88 \pm 6.88^{a}$ & $14.82 \pm 6.90^{\mathrm{bcd}}$ & $3.03 \pm 0.78^{\mathrm{ab}}$ \\
\hline 2 & 0.03 & $50.86 \pm 5.24^{\mathrm{abcd}}$ & $17.47 \pm 4.07^{\mathrm{b}}$ & $28.53 \pm 8.22^{\mathrm{ab}}$ & $1.92 \pm 0.57^{\mathrm{ab}}$ \\
\hline 2 & 0.05 & $45.32 \pm 6.26^{\text {bcdef }}$ & $17.20 \pm 9.18^{b}$ & $24.25 \pm 3.46^{\mathrm{abc}}$ & $3.18 \pm 0.65^{\mathrm{ab}}$ \\
\hline 4 & 0 & $35.43 \pm 7.99^{\text {bcdefg }}$ & $16.15 \pm 1.94^{\mathrm{b}}$ & $11.31 \pm 2.63^{\mathrm{bcd}}$ & $4.33 \pm 1.68^{\mathrm{a}}$ \\
\hline 4 & 0.01 & $25.93 \pm 4.02^{\mathrm{efg}}$ & $22.65 \pm 7.30^{\mathrm{b}}$ & $5.47 \pm 1.90^{\mathrm{d}}$ & $0.36 \pm 0.12^{\mathrm{b}}$ \\
\hline 4 & 0.03 & $28.46 \pm 5.94^{\mathrm{defg}}$ & $9.78 \pm 1.64^{\mathrm{b}}$ & $14.49 \pm 6.77^{\mathrm{bcd}}$ & $4.04 \pm 7.72^{\mathrm{a}}$ \\
\hline 4 & 0.05 & $35.66 \pm 2.27^{\text {bcdefg }}$ & $10.52 \pm 2.88^{b}$ & $11.37 \pm 7.87^{\mathrm{bcd}}$ & $1.21 \pm 0.22^{77 a b}$ \\
\hline 6 & 0 & $49.22 \pm 4.73^{\mathrm{abcde}}$ & $20.25 \pm 2.04^{b}$ & $27.23 \pm 7.80^{\mathrm{ab}}$ & $1.44 \pm 0.73^{\mathrm{ab}}$ \\
\hline 6 & 0.01 & $28.00 \pm 1.14^{\operatorname{defg}}$ & $14.81 \pm 9.84^{b}$ & $11.33 \pm 3.27^{\mathrm{bcd}}$ & $0.87 \pm 0.93^{\mathrm{ab}}$ \\
\hline 6 & 0.03 & $24.07 \pm 2.95^{\mathrm{fg}}$ & $18.52 \pm 3.16^{\mathrm{b}}$ & $13.20 \pm 2.23^{\mathrm{bcd}}$ & $1.42 \pm 0.11^{\mathrm{ab}}$ \\
\hline 6 & 0.05 & $40.97 \pm 7.30^{\mathrm{g}}$ & $18.35 \pm 7.71^{\mathrm{b}}$ & $1.93 \pm 2.99^{\mathrm{d}}$ & $0.00 \pm 0.00^{\mathrm{b}}$ \\
\hline
\end{tabular}

Note: *Within a column, percentage values that are followed by the same letter are not statistically significant according to the Duncan test at a $5 \%$ level of significance. 


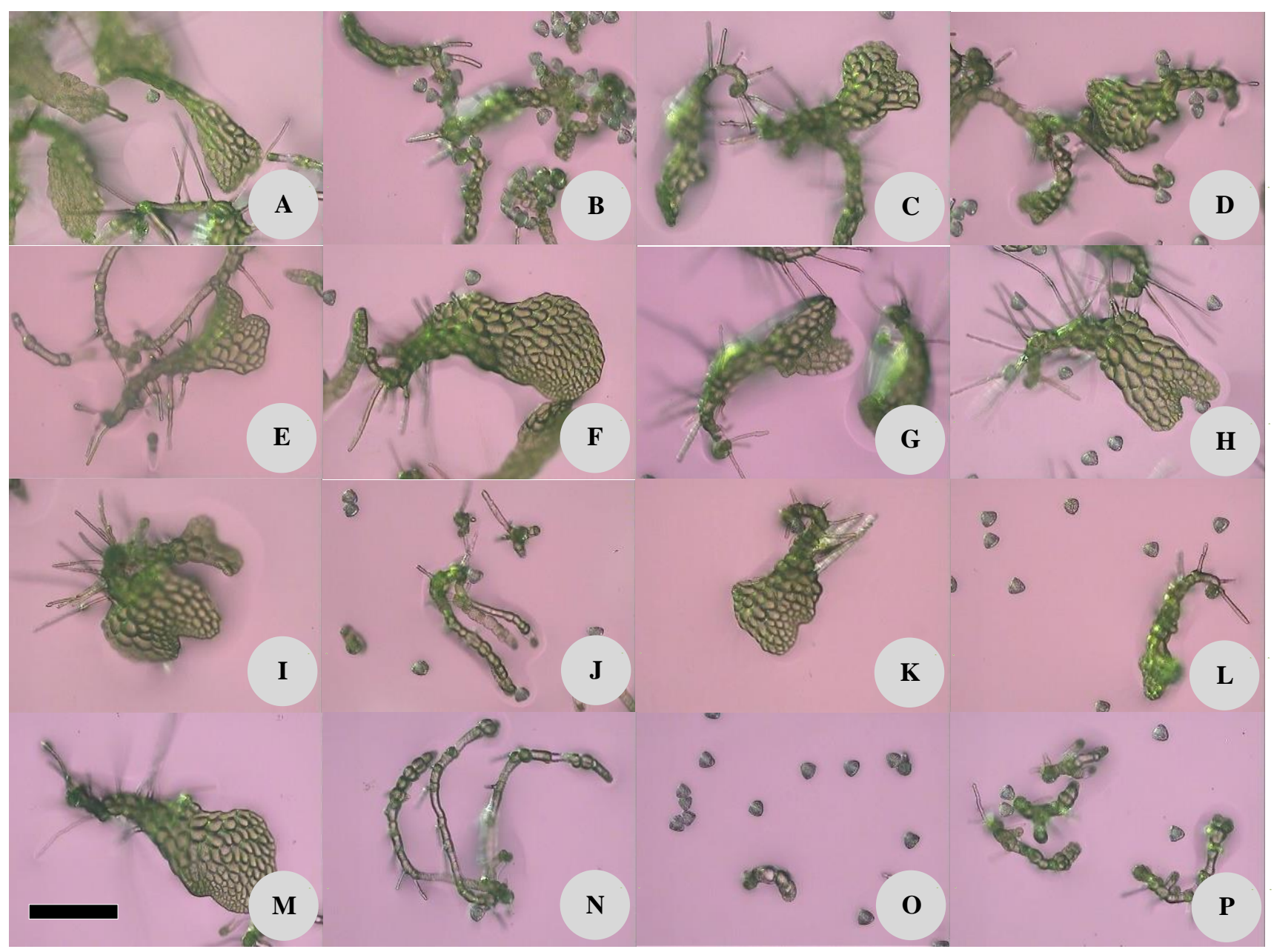

Figure 2. Microscopic appearence of the spores germination and early gametophytes development of Cibotium barometz (collection number: TNgP 3353) observed at 61 days after sowing on Petri Dishes containing MS media supplemented with BAP and NAA: A. 0 $\mathrm{mgL}^{-1}$ and $0 \mathrm{mg} \mathrm{L}^{-1}$, B. $0 \mathrm{mg} \mathrm{L}^{-1}$ and $0,01 \mathrm{mg} \mathrm{L}^{-1}$, C. $0 \mathrm{mg} \mathrm{L}^{-1}$ and $0,03 \mathrm{mg} \mathrm{L}^{-1}$, D. $0 \mathrm{mg} \mathrm{L}^{-1}$ and $0,05 \mathrm{mg} \mathrm{L}^{-1}$, E. $2 \mathrm{mg} \mathrm{L}^{-1}$ and $0 \mathrm{mg} \mathrm{L}^{-1}$, F. $2 \mathrm{mg} \mathrm{L}^{-1}$ and $0,01 \mathrm{mg} \mathrm{L}^{-1}$, G. $2 \mathrm{mg} \mathrm{L}^{-1}$ and $0,03 \mathrm{mg} \mathrm{L}^{-1}$, H. $2 \mathrm{mg} \mathrm{L}^{-1}$ and $0,05 \mathrm{mg} \mathrm{L}^{-1}$, I. $4 \mathrm{mg} \mathrm{L}^{-1}$ and $0 \mathrm{mg} \mathrm{L}^{-1}$, J.4 $\mathrm{mg} \mathrm{L}^{-1}$ and $0,01 \mathrm{mg} \mathrm{L}^{-1}$, K. $4 \mathrm{mg} \mathrm{L}^{-1}$ and $0,03 \mathrm{mg} \mathrm{L}^{-1}$, L. $4 \mathrm{mg} \mathrm{L}^{-1}$ and $0,05 \mathrm{mg} \mathrm{L}^{-1}$, M. $6 \mathrm{mg} \mathrm{L}^{-1}$ and $0 \mathrm{mg} \mathrm{L}^{-1}$, N.6 $\mathrm{mg} \mathrm{L}^{-1}$ and $0,01 \mathrm{mg} \mathrm{L}^{-1}, \mathrm{O} .6 \mathrm{mg} \mathrm{L}^{-1}$ and 0,03 $\mathrm{mg} \mathrm{L}^{-1}$, P. $6 \mathrm{mg} \mathrm{L}^{-1}$ and $0,05 \mathrm{mg} \mathrm{L}^{-1}$. Bar $=400 \mu \mathrm{m}$ for all.

In conclusion, this is the first report that describes the in vitro germination and early gametophyte of $C$. barometz, one of the endangered species of tree ferns of Indonesia. In vitro spore germination of C. barometz from Sumatra is Vittaria-type, and the prothallial development is classified as Drynaria-type. Young heart-shape gametophytes consisting of 110-240 cells were formed in 45-61 days after sowing. The two best spore culture media for rapid spore germination and development of the gametophytes of $C$. barometz were $1 / 2$ MS without supplementation, and $1 / 2$ MS supplemented with $2 \mathrm{mg} \mathrm{L}^{-1} \mathrm{BAP}$. The basal medium of $1 / 2$ MS, with or without BAP supplementation at $2 \mathrm{mg} \mathrm{L}^{-1}$ may be used for in vitro propagation of the closely related species to $C$. barometz and scaly tree fern species.

\section{ACKNOWLEDGEMENTS}

Two authors contributed equally to this work, discussed the results and commented on the manuscripts at all stages.
This research was funded by a Grant-in-Aid for Scientific Research from Program Kompetitif LIPI TA 2013-2014 and Program Unggulan LIPI TA 2015. We are grateful to the staff of the Tissue Culture Laboratory of Bogor Botanic Gardens for their assistance. We would also like to thank Dr. Graham Eagleton (Australia) for reading and correcting the first manuscript.

\section{REFERENCES}

Abbasi H. 2017. Indirect organogenesis in milkweed (Calotropis procera) from mature zygotic embryo explants. Biotechnologia 98 (3): 189194. DOI: $10.5114 /$ bta.2017.70797.

AL-Wajeeh NS, Hajerezaie M, Noor SM, Halabi MF, Al-Henhena N, Azizan AHS, Abdulla M A. 2017a. The gastroprotective effects of Cibotium barometz hair on ethanol-induced gastric ulcer in SpragueDawley rats. BMC Vet Res 13 (27): 1-12. DOI: 10.1186/s12917-0170949-z.

Al-Wajeeh NS, Hajrezaie M, Al-Henhena N, Kamran S, Bagheri, E, Zahedifard M, Abdulla MA. 2017b. The antiulcer effect of Cibotium barometz leaves in rats with experimentally induced acute gastric 
ulcer. Drug Design, Develop Therapy 11: 995-1009. DOI: 10.2147/DDDT.S107018.

Ballesteros D, Pence VC. 2018. Fern conservation: Spore, gametophyte, and sporophyte ex situ storage, in vitro culture, and cryopreservation. Curr Adv Fern Res 227-249. DOI: 10.1007/978-3-319-75103-0_11.

Bertrand AM, Albuerne MA, Fernandez H, Gonzalez A, Sanchez-Tames R. 1999. In vitro organogenesis of Polypodium cambricum. Plant Cell Tissue Organ Cult 57: 65-69.

Camloh H. 1993. Spore Germination and Early Gametophyte Development of Platycerium bifurcatum. Amer Fern J 83 (3): 79-85.

Castilho CVV, Neto JFF, Leitão SG, Barreto CS, Pinto SC, da Silva NCB 2018. Anemia tomentosa var. anthriscifolia in vitro culture: sporophyte development and volatile compound profile of an aromatic fern. Plant Cell, Tissue Organ Cult 133 (3): 311-323. DOI: 10.1007/s11240-018-1383-z.

Chen SM, Deng HP, Liu GH, Han M. 2007. Gametophyte development and its diversity in Cibotium barometz. Xibei Zhiwu Xuebao 27 (3): 460-463.

Cho JS, Han JH, Lee CH. 2017. Effects of medium components and composition on mass propagation of Arachniodes aristata (G. Forst.) tindale. Korean J Hort Sci Tech 35 (1), 131-141. DOI: 10.12972/kjhst.20170014.

Chuter AE, Jordan GJ, Dalton PJ, Wapstra W. 2008. Spore germination and early gametophyte development of the soft tree fern Dicksonia antartica. Tasforest 17: 1- 5.

CITES Secretary. 2006. The List of CITES national export quotas for 2006. https: //cites.org/sites/default/files/common/quotas/2006/Export Quotas2006.pdf. [Accessed 04 April 2016].

CITES Secretary. 2007. The List of CITES national export quotas for 2007. https: //cites.org/sites/default/files/common/quotas/2006/Export Quotas2007.pdf. [Accessed 04 April 2016].

CITES Secretary. 2008. The List of CITES national export quotas for 2008. https: //cites.org/sites/default/files/common/quotas/2006/Export Quotas2008.pdf. [Accessed 04 April 2016].

CITES Secretary. 2009. The List of CITES national export quotas for 2009. https: //cites.org/sites/default/files/common/quotas/2006/Export Quotas2009.pdf. [Accessed 04 April 2016].

CITES Secretary. 2010. The List of CITES national export quotas for 2010. https: //cites.org/sites/default/files/common/quotas/2006/Export Quotas2010.pdf. [Accessed 04 April 2016]

CITES Secretary. 2011. The List of CITES national export quotas for 2011. https: //cites.org/sites/default/files/common/quotas/2006/Export Quotas2011.pdf. [Accessed 04 April 2016].

CITES Secretary. 2012. The List of CITES national export quotas for 2012. https: //cites.org/sites/default/files/common/quotas/2006/Export Quotas2006.pdf. [Accessed 04 April 2016].

CITES Secretary. 2013. The List of CITES national export quotas for 2013. https: //cites.org/sites/default/files/common/quotas/2006/Export Quotas2006.pdf. [Accessed 04 April 2016].

CITES Secretary. 2014. The List of CITES national export quotas for 2014. https: //cites.org/sites/default/files/common/quotas/2006/Export Quotas2014.pdf. [Accessed 04 April 2016].

CITES Secretary. 2015. The List of CITES national export quotas for 2015. https: //cites.org/sites/default/files/common/quotas/2015/Export Quotas2015.pdf. [Accessed 04 April 2016].

Deng HP, Liu GH, Wu L, Liao XM, Chen SM, Cui YQ. 2007. Observation on gametophyte development of Cibotium barometz. Zhongguo Zhong Yao Za Zhi 32 (18): 1850-1853.

Ebihara A, Fraser-Jenkins CR, Parris BS, Zhang X-C, Yang Y-H, Chiou W-L, Chang H-M, Lindsay S, Middleton D, Masahiro Kato M, Praptosu wiryo TNg, Amoroso VB, Barcelona JF, Ranil RHG, Park CH, N. Murakami M, Hoya A. 2012. Rare and threatened Pteridophytes of Asia 1. An enumeration of narrowly distributed taxa. Bul Nat Nat Sci Series B (Botany) 38 (3): 93-119.

Ebihara A, Nitta JH. 2019. An update and reassessment of fern and lycophyte diversity data in the Japanese Archipelago. J Plant Res 132: 723-738

Elgabra M, El-Keblawy A, Mosa KA, Soliman S. 2019. Factors controlling seed dormancy and germination response of Brachypodium hybridum growing in the hot arid mountains of the Arabian desert. Botany 97 (7): 371-379. DOI: 10.1139/cjb-2018-0207

Farfán-Santillán N, Mendoza-Ruiz A, Pérez-García B, Velázquez-Montes E. 2017. Gametophyte development in Mexican species of Gleicheniaceae ferns. Rev Biol Tropi 65 (3): 939-952. DOI: $10.15517 /$ rbt.v65i3.26346
Fernandez H, Bertrand AM, Sanchez-Tames R. 1999. Biological and nutritional aspects involved in fern multiplication. Plant Cell Tissue Organ Cult 56: 211-214

Fernandez H, Revilla MA. 2003. In-vitro culture of ornamental ferns. Plant Cell Tissue Organ Cult 73: 1-13

Fu C, Zheng C, Lin J, Ye J, Mei Y, Pan C, Liu X. 2017. Cibotium barometz polysaccharides stimulate chondrocyte proliferation in vitro by promoting G1/S cell cycle transition. Molecular Medicine Reports, 15 (5), 3027-3034. DOI: $10.3892 / \mathrm{mmr} .2017 .6412$.

Gabriel y Galán JM, Prada C, Martínez-Calvo C, Lahoz-Beltrá R. 2015. A Gompertz regression model for fern spores germination. Anal Jard Bot Madrid 72 (1): 10-15. DOI: 10.3989/ajbm.2405.

Given DR. 2002. Needs, methods and means (keynote lecturer). Proceedings of the International Symposium at the University of Surrey, Guildford, UK 23-26 July 2001. Fern Gaz 16 (6- 8): 269-277.

Goller K, Rybczyński JJ. 2007. Gametophyte and sporophyte of tree ferns in vitro culture. Acta Soc Botanic Pol 76 (3): 193-199.

Gorrer DA, Cayetano Berrueta P, Ramos Giacosa JP, Giudice GE, Luján Luna M. 2018. Morfogénesis de la fase sexual de los helechos epífitos Microgramma mortoniana y Pleopeltis macrocarpa (Polypodiaceae) reserva Natural Punta Lara, Buenos Aires, Argentina. Rev Biol Trop 66 (3): 1078-1087. DOI: 10.15517/rbt.v66i3.31775.

He J, Li X, Wang Z, Bennett S, Chen K, Xiao Z, Lin D. 2019. Therapeutic anabolic and anticatabolic benefits of natural Chinese medicines for the treatment of osteoporosis. Front Pharmacol 10 (1344): 1-23. DOI: 10.3389/fphar.2019.01344.

Heng YW, Ban JJ, Khoo KS, Sit NW. 2020. Biological activities and phytochemical content of the rhizome hairs of Cibotium barometz (Cibotiaceae). Industr Crops Prod 153. DOI: 10.1016/j.indcrop.2020.112612.

Higuchi H, Amaki W. 1989. Effect of 6-benzylaminopurine on the organogenesis of Asplenium nidus L. through in vitro propagation. Sci Hort 37: 351-359.

Holttum RE. 1963. Cyatheaceae. In CGGJ. Van Steenis and RE. Holttum [eds.] Flora Malesiana. Martinus Nijhoff, The Hague, Netherlands.

Huang D, Zhang M, Chen W, Zhang D, Wang X, Cao H, Yan C. 2018a. Structural elucidation and osteogenic activities of two novel heteropolysaccharides obtained from water extraction residues of Cibotium barometz. Industrial Crops Prod 121: 216-225. DOI: 10.1016/j.indcrop.2018.04.070.

Huang D, Zhang M, Yi P, Yan C. 2018b. Structural characterization and osteoprotective effects of a novel oligo-glucomannan obtained from the rhizome of Cibotium barometz by alkali extraction. Industrial Crops Prod 113: 202-209. DOI: 10.1016/j.indcrop.2018.01.034.

Isnaini Y. 2013. Perkecambahan In vitro Dua Jenis Kantong Semar (Nepenthes ampullaria dan N. rafflesiana.) Asal Pulau Batam. In Kartika JG.; Suwarna WB; Ardhie SW; El Sanura CP; Fitriana FN. (eds). Membangun Sistem Baru Agribisnis Hortikultura Indonesia pada Era Pasar Global. Prosiding Seminar Nasional Perhorti, Institut Pertanian Bogor, Bogor. 9 Oktober 2013. [Indonesian]

Jang BK, Cho JS, Lee KC, Lee CH. 2017. Culture conditions affecting spore germination, prothallus propagation and sporophyte formation of Dryopteris nipponensis Koidz. Hort Sci Tech 35 (4): 480-489. DOI: 10.12972/kjhst.20170051

Jang BK, Cho JS, Lee CH. 2019a. Propagation methods for gametophyte proliferation and sporophyte formation in silver cloak fern (Cheilanthes argentea). Hort Environ Biotech 60 (3): 435-442. DOI: 10.1007/s13580-019-00128-6.

Jang BK, Cho JS, Park K, Lee CH. 2019b. A methodology for large-scale Athyrium sheareri gametophyte proliferation and sporophyte production using tissue culture. In vitro Cell Develop Biol - Plant 55 (5): 519-526. DOI: 10.1007/s11627-019-09991-5.

Jang BK, Cho JS, Park K, Lee CH. 2020. Practical methodology for gametophyte proliferation and sporophyte production in green penny fern (Lemmaphyllum microphyllum C. Presl) using mechanical fragmentation. In vitro Cell Develop Biol - Plant 56 (3): 318-324. DOI: $10.1007 / \mathrm{s} 11627-020-10055-2$.

Johnson M, Shibila T. 2018. In vitro spore culture and ontogeny of Elaphoglossum stigmatolepis (Fee) Moore. Phytomorphology 68 (12): 35-38.

Khan K, Raziq M, Kayani HA. 2008. In vitro propagation of bird's nest fern (Asplenium nidus) from spores. Pak J Bot 40 (1): 91-97.

Kwon HJ, Han JH, Lee CH, Kim SY. 2017. Conditions of in vitro spore germination and prothallium culture for sporophyte propagation of Polystichum braunii (Spenn.) Féé. J Plant Biotech 44 (4): 454-461. DOI: 10.5010/JPB.2017.44.4.454 
Li X, Ye QM, Zhan QC, Kang BL, Jian LG, Huang ML. 2010. In vitro culture and plant regeneration of Cibotium barometz, (L.) J.Sm. Northern Hort 6: 152-155.

Lim TK, Lim TK. 2016. Cibotium barometz. In Edible Medicinal and Non-Medicinal Plants (pp. 82-91). Springer Netherlands. DOI: 10.1007/978-94-017-7276-1 4

Liu S, Wang Z, Wang T, Su Y. 2018. The complete chloroplast genome of Cibotium barometz (Cibotiaceae), an endangered CITES medicinal fern. J Mitochondrial DNA Part B: Resources 3 (1): 464-465. DOI: $10.1080 / 23802359.2018 .1462128$

Luna ML, Yañez A, Giacosa JPR, Gorrer D, Berrueta PC, Giudice GE. 2016. In vitro spore culture and reproductive aspects of the annual fern Anogramma chaerophylla (Pteridaceae). Bol de La Soc Argentina de Bot 51 (4): 675-682. DOI: 10.31055/1851. 2372. v51. $\mathrm{n} 4.16356$

Makowski D, Tomiczak K, Rybczyński JJ, Mikuła A. 2016. Integration of tissue culture and cryopreservation methods for propagation and conservation of the fern Osmunda regalis L. Acta Physiol Plant 38 (1): 1-12. DOI: 10.1007/s11738-015-2037-y

Manonmani R, Sara SC. 2014. In vitro early ontogenic studies of Actiniopteris radiata (Swartz) Link. under different medium. Inter J of Pharma Biol Sci 5 (1): 483-491.

Marcon C, Silveira T, Bender D, Droste A. 2015. Spore germination and gametophytic development of Cyathea atrovirens (Langsd. \& Fisch.) Domin (Cyatheaceae) at different temperatures and photoperiods. Ambiência 11 (2): 409-422. DOI: 10.5935/ambiencia.2015.02.10.

Mehltreter, K. 2010. Fern conservation. In: Mehltreter K, Walker LR, Sharpe JM (eds.). Fern Ecology. Cambridge University Press, New York.

Moura IR, Simões-Costa MC, Silva MJ, Duarte MC. 2015. Spore-derived in vitro cultures from Herbarium specimens of Cape Verde ferns. Acta Hort 1083: 273-279. International Society for Horticultural Science. DOI: 10.17660/ActaHortic.2015.1083.34.

Musman M, Widayanti P, Erlidawati E. 2020. Antioxidant and antitermite activities of the ethanol extract of Cibotium barometz (L.) J Sm. J Physics: Conf Ser 1460: 1-6. DOI: 10.1088/1742-6596/ 1460/1/012081.

Nayar BK, Kaur S. 1969. A reinvestigation of the morphology of the gametophyte and juvenile sporophyte of Ceratopteris thalictroides. Can J Bot 47 (3): 395-404. DOI: 10.1139/b69-054.

Nguyen T, Le TS, Ngo DP, Nguyen QN, Pham TH, Nguyen TH. 2009. Non-detriment find-ing for Cibotium barometz in Vietnam. SC58 Doc. 21.1. Annex 2. https: //www.cites.org/sites/default/files/ndf material/Non-detriment $\% 20$ finding $\% 20$ for $\% 20$ Cibotium $\%$ 20barometz\%20in\%20Viet\%20Nam.pdf

Oloyede FA, Olatunji TY, Ogbimi ER. 2017. Spore germination, gametophyte development and studies of the growth rate of Adiantum capillus-veneris L. Notulae Sci Biol 9 (4): 557-562. DOI: $10.15835 / \mathrm{nsb} 9410117$

Penfield S. 2017. Seed dormancy and germination. Current Biology. 27 (17): 874-878. DOI: 10.1016/j.cub.2017.05.050.

Praptosuwiryo TNg. 2003. Cibotium barometz. (L.) J. Smith. In: de Winter WP, Amoroso VB (eds.). Plant Resources of South-East Asia 15 (2) Cryptogams: Ferns and Ferns Allies. Prosea, Bogor.

Praptosuwiryo TNg, Pribadi DO, Puspitaningtyas DM, Hartini S. 2011 Inventorying of the tree fern genus Cibotium of Sumatra: Ecology, population size and distribution in North Sumatra. Biodiversitas 12 (4): 204-211

Praptosuwiryo TNg, Pribadi DO, Rugayah. 2015. Growth, development and morphology of gametophytes of golden chicken fern (Cibotium barometz) in natural media. Biodiversitas 16 (2): 303-310.

Praptosuwiryo TNg, Puspitaningtyas DM, Pribadi DO, Rugayah.. 2017. Population Study of the Golden Chicken Fern (Cibotium barometz (L.) J. Sm. in Riau Province, Sumatra. J Trop Life Sci 7 (2): 167-176. DOI: $10.11594 /$ jtls.07.02.13

Praptosuwiryo TNg, Rugayah. 2017. Cibotiaceae (Paku tiang-paku tiangan). In: Rugayah, Yulita KS, Arifiani D, Rustiami H, Girmansyah D (Eds), Tumbuhan Langka Indonesia: 50 tumbuhan terancam kepunahan. LIPI Press, Jakarta. [Indonesian]

Rechenmacher C, Schmitt JL, Droste A. 2010. Spore germination and gametophyte development of Cyathea atrovirens (Langsd. \& Fisch.) Domin (Cyatheaceae) under different $\mathrm{pH}$ conditions. Braz J Biol 70: $1155-1160$.

Ravi BX. 2016. In vitro polyembryony induction in a critically endangered fern Pteris tripartita Sw. Asian Pacific Journal of Reproduction 5 (4): 345-350. DOI: 10.1016/j.apjr.2016.06.012.
Rocha DI, Monte-Bello CC, Dornelas MC. 2015. Alternative induction of de novo shoot organogenesis or somatic embryogenesis from in vitro cultures of mature zygotic embryos of passion fruit (Passiflora edulis Sims) is modulated by the ratio between auxin and cytokinin in the medium. Plant Cell, Tissue and Organ Culture, 120 (3): 1087-1098. DOI: 10.1007/s11240-014-0663-5.

Romanenko KO, Kosakivska IV, Babenko LM, Vasheka OV, Romanenko PO, Negretsky VA, Minarchenko VM. 2019. Effects of exogenous cytokinins on spore germination and gametophyte morphogenesis of Dryopteris filix-mas (L.) Schott in vitro culture. Cytology and Genetics, 53 (3): 192-201. DOI: 10.3103/S0095452719030034.

Rugayah, Praptosuwiryo TNg, Puspitaningtyas DM. 2009. Morphological Variation of Cibotium barometz from West Sumatra. In: Sancayaningsih EP, Sembiring L, Mulyati, Semiarti E. (eds.). Advance in Biological Sciences; Proceedings on The International Conference on Biological Science. Gadjah Mada University, Yogyakarta. 16-17 October 2009. [Indonesian].

Schippmann U. 2018. Plant Annotations in the CITES Appendices. An illustrated manual. Version 2.0. BfN-Skripten 495.

Shelikhan LA. 2020. In vitro culture of the rare fern Polystichum craspedosorum (Maxim.) Diels. Botanica Pacifica 9 (1): 91-95. DOI: 10.17581/bp.2020.09102.

Simões-Costa MC, Moura IR, Silva MJ, Duarte MC. 2015. In vitro culture of spores from Woodwardia fimbriata Smith. Acta Horticulturae 1083: 281-285. DOI: 10.17660/ActaHortic.2015.1083.35.

Singh AP, Johari D, Khare PB. 2017. Studies on ontogeny and reproductive behaviour of Lepisorus nudus (Hook.) Ching (Polypodiaceae). J Plant Res 130 (2): 281-290. DOI: 10.1007/s10 265 -016-0891-3

Sit NW, Chan YS, Lai SC, Lim LN, Looi GT, Tay PL, Ong HC. 2018. In vitro antidermatophytic activity and cytotoxicity of extracts derived from medicinal plants and marine algae. J de Mycol Med 28 (3): 561567. DOI: 10.1016/j.mycmed.2018.07.001.

Smith AR, Pryer KM, Schuettpelz E, Korall P, Schneider H, Wolf PG. 2006. A classification for extant fern. Taxon 55: 705-731.

Smýkalová I, Vrbová M, Cvečková M, Plačková L, Žukauskaité A, Zatloukal M, Griga M. 2019. The effects of novel synthetic cytokinin derivatives and endogenous cytokinins on the in vitro growth responses of hemp (Cannabis sativa L.) explants. Plant Cell Tissue Organ Cult 139 (2): 381-394. DOI: 10.1007/s11240-019-01693-5.

Steinbrecher T, Leubner-Metzger G. 2017. The biomechanics of seed germination. J Exp Bot 68 (4): 765-783. DOI: 10.1093/ jxb/ erw428

Suo J, Chen S, Zhao Q, Shi L, Dai S. 2015. Fern spore germination in response to environmental factors. Front Biol 10 (4): 289-296. DOI: 10.1007/s11515-015-1342-6.

UNEP-WCMC [United Nations Environment Programme World Conservation Monitoring Centre]. 2010. Review of Cibotium barometz and Flickingeria fimbriata from Viet Nam. UNEP-WCMC, Cambridge.

Van Nguyen Q, Khuat HT, Nguyen YNT, Vu DT, Bui TH, Boo KH. 2020. Drynaria bonii spore culture: optimization of culture conditions and analysis of gametophyte and sporophyte development. Plant Biotech Reports 14: 575-584. DOI: 10.1007/s11816-020-00632-7.

Wang D, Markus J, Wang C, Kim YJ, Mathiyalagan R, Aceituno VC, Yang DC. 2017. Green synthesis of gold and silver nanoparticles using aqueous extract of Cibotium barometz root. Artificial Cells, Nanomed Biotech 45 (8): 1548-1555. DOI: $10.1080 / 21691401.2016 .1260580$.

Wang H, Zhang G, Ke L, Liu B, Zhang S, Deng C. 2017. Understanding the effects of 3D porous architectures on promoting lithium or sodium intercalation in iodine/C cathodes synthesized: Via a biochemistryenabled strategy. Nanoscale 9 (27): 9365-9375. DOI: 10.1039/ c7nr02311a.

Xie MP, Li L, Sun H, Lu AQ, Zhang B, Shi JG, Wang SJ. 2017. Hepatoprotective hemiterpene glycosides from the rhizome of Cibotium barometz (L.) J. Sm. Phytochemistry 138: 128-133. DOI: 10.1016/j.phytochem.2017.02.023.

Yan A, Chen Z. 2020. The control of seed dormancy and germination by temperature, light and nitrate. Botanical Review 86 (1): 39-75. DOI: 10.1007/s12229-020-09220-4.

Yu R, Cheng X, Zhang G, Li H, Gui M. 2016a. Observation on gametophyte development and apogamy of the endangered fern Cibotium barometz. Plant Physiology J 52 (8): 1305-1311. DOI: 10.13592/j.cnki.ppj.2016.0268

Yu R, Zhang G, Li H, Cao H, Mo X, Gui M, Wang J. 2016b. In vitro propagation of the endangered tree fern Cibotium barometz through 
formation of green globular bodies. Plant Cell, Tissue Organ Culture 128 (2), 369-379. DOI: 10.1007/s11240-016-1116-0.

Zhang XC, Jia JS, Zhang GM. 2008. Non-detriment finding for Cibotium barometz in China. NDF Workshop Case Studies. WG 2 - Perennials. Case Study 1: Cibotium barometz. Pp. 1-8.

Zhang W, Wang Q, Chen G, Chen H. 2020. Partial tissue culture and rapid propagation of Phymatosorus scolopendria spores. Zhiwu Shengli
Xuebao/Plant Physiology J 56 (4): 856-862. DOI: $10.13592 /$ j. cnki. ppj.2019.0466.

Zhang XC, Jia JS, Zhang GM. 2002. Survey and evaluation of the natural resources of Cibotium barometz (L.) J. Smith in China, with reference to the implementation of CITES. The fern Gazette 16: 383-392. 